\section{Politics, UNESCO, and Higher Education: A Case Study}

\section{Alma Maldonado-Maldonado and Antoni Verger}

Alma Maldonado-Maldonado is assistant professor at the Center for the Study of Higher Education, University of Arizona. E-mail: almaldo2@gmail.com. Antoni Verger is lecturer and postdoctoral researcher at AMIDSt, University of Amsterdam, Netherlands. E-mail: a.verger@uva.nl.

$\mathrm{O}$ Wednesday, July 8, 2009, at 5:00 pm (Paris time), the World Conference on Higher Education steering-committee chairperson read the conference's final communiqué. The entire assembly of 199 United Nations Educational, Scientific, and Cultural Organization (UNESCO) member countries, approved it by consensus and with acclamations. The chairperson reported that 20 observers followed the drafting committee's work. Two of these observers are the authors of this article, offering a behind-the-scenes account of the events that occurred before the final communiqué's presentation. In contrast to the general calm atmosphere predominating during the conference sessions, the drafting process was notable for passionate debates and tense negotiations among members, as they worked to craft the final document.

The I998 UNESCO World Conference on Higher Education agreed on a very relevant final declaration that helped to generate common understandings at the global level on the definition of higher education and the main challenges to be faced by governments and stakeholders. Because of this, we think it is important to detail the content and the "politics of higher education" behind the redaction of the second World Conference on Higher Education's final communiqué (http://www.unesco.org/en/wche2009/resources/conferencedocuments/).

\section{Drafting Process}

Before the world conference, a series of regional conferences were convened. Each of the regional conferences' final declarations served as the main input for the final communiqué's first draft presented to the drafting committee. The committee included I7 UNESCO member states (Germany, France, the United States, Venezuela, India, Brazil, Jamaica, Romania, Azerbaijan, Pakistan, Madagascar, RD Congo, Morocco, South Africa, China, Palestine, and Sudan), the chairperson (from Russia), one UNESCO representative, four higher education experts, three stakeholders (International Association of Universities, Education International, and European Students' Union), two general rapporteurs, and three drafters.

Five meetings, over three days, were scheduled to draft the final document. The first day's two meetings were spent discussing the drafting committee's general procedures. On the second day, content discussions began. Two meetings were held that day, the first one at noon and the second one in the evening. The latter started at 7:30 pm and ended after $2 \mathrm{am}$. Undoubtedly, this was the most intense drafting-process day.

\section{Three Contentious Issues}

During the drafting process, most of the political discussion concerned the following issues, although not exclusively.

Defining higher education. The most complicated issue to reach agreement involved defining higher education's meaning. The first draft stated: "Higher education plays an important role in nation-building. Higher education as a public good must be a matter of responsibility of all governments." The revised final communiqué states: "Higher education as a public good and a strategic imperative for all levels of education and as the basis for research, innovation, and creativity must be a matter of responsibility and economic support of all governments." Between the first and final drafts, middle-stage iterations included: "Higher education is a social public good and a human right" (3rd draft) to more market-driven conceptions of higher education as a "public service" (5th draft). The Latin American countries strongly advocated the $3 \mathrm{rd}$-draft wording, while the United States was reluctant to accept the use of the "public-good" category. Extended negotiations were necessary to resolve this major disagreement. On the conference's last day, India's and Brazil's representatives negotiated with the United States to accept the use of "public good." It is unclear exactly what was negotiated, but it may have been the elimination of the paragraph on the General Agreement on Trade in Services (GATS), as shown below. For the United States, the use of the adverb "as" was more acceptable than the verb "to be" (higher education is a public good). Even so, the final wording might still be perceived as too problematic for some countries, such as the United States itself, that support higher levels of market intervention in the field.

On the conference's last day, India's and Brazil's representatives negotiated with the United States to accept the use of "public good."

GATS and trade in higher education. The GATS debate consumed a lot of time during the drafting process. The first draft stated: "Trade in services is a manifestation of globalization that has caused great concern in the academic community; in particular with GATS under the WTO (World Trade Organization). Member states should not consider higher education as a commercial transaction. ..." Again, the discussion centered on disagreement between the United States and Latin American countries. The latter pushed for keeping this point in the communiqué, as it could strengthen their position on higher education as a public good. But the United States was opposed to its inclusion, arguing that UNESCO is not the 
forum to discuss GATS, and that the global market of higher education can coexist with a more state-driven sector.

Romania also backed the United States, arguing that Romanians have already liberalized higher education using GATS. As a consequence, Romanians felt that it would be unreasonable to accept the content of this paragraph when their behavior in the context of the WTO/GATS is the opposite. After a long and normative discussion on whether education should or should not be considered a commodity, Brazil and Venezuela, surprisingly, accepted the deletion of the paragraph in its entirety. As a result, the final communiqué contains no mention of GATS.

\section{The result of these tensions for the World} Conference on Higher Education was a protracted yet fragmented communiqué that, in our opinion, does not transmit a clear and coherent message to the higher education international community.

Worldwide university rankings. The initial draft stated: "Globalization has also increased the pressure to make comparisons between higher education institutions, resulting in the emergence of international rankings. Such comparisons should promote institutional diversity by including a range of criteria that reflect the variety of goals and purposes of different systems, institutions, and institution types...." By the second draft, the paragraph had been revised to read: "Comparisons, in order to be useful, must be based on quality data and appropriate analysis reflecting the diversity of systems and institutional missions." The word "ranking" had disappeared from this draft and was never included again. The Indian representative strongly and repeatedly requested elimination of the ranking concept from the communiqué. Never clear were the objections on the use of this term. The main debates involved the "solution" based on rather erasing the topics that had strong opposition than continuing to discuss them.

\section{Final Results}

The final draft needed to be approved by the third day. Time pressures, exhaustion, and last-minute negotiations in the corridors had a combined effect in reaching this objective. As a consequence, certain contentious topics were resolved (or "unresolved") by simply deleting them from the document (i.e., discussions involving GATS and rankings). Another factor induced countries to reach consensus: No one wanted to stall the drafting process and, as a consequence, be singled out as being responsible for the failure of the conference.

In total, six drafts were necessary to compose the final communiqué and a lot of negotiations and frame-bridging to satisfy all the interests and ideas involved, which included progres- sive demands (represented by the Latin American countries) and strong promarket statements (specifically pushed by the United States). In the Latin American case, this position finds an explanation in the current wave of left-wing governments in the region that push for a bigger presence of the state in the provision of a range of public services-higher education among them. In the US case, the influence of the new administration has not been reflected in changes on the traditional country's positions in UNESCO. The result of these tensions for the World Conference on Higher Education was a protracted yet fragmented communiqué that, in our opinion, does not transmit a clear and coherent message to the higher education international community. It is still too soon, however, to judge its political relevance. In the meantime, we hope that these insider notes contribute to explaining the form and the content, but especially, the omissions pertaining to the 2009 final communiqué.

\section{The Future of International Postsecondary Student}

\section{Enrollments}

\section{Madeleine F. Green and Kimberly Koch}

Madeleine F. Green is vice president for international initiatives at the American Council on Education, Washington, DC; Kimberly Koch is former program associate at ACE. E-mail: madeleine_green@ace.nche.edu.

A ccording to the United Nations Educational, Scientific, and Cultural Organization, there were an estimated 2.8 million internationally mobile students worldwide, up from I.8 million in 1999. UNESCO defines an international student as one who crossed his or her national border to pursue an education and excludes students who are in a program for less than one year.

Governments and higher education institutions support the recruitment and enrollment of international students for a variety of reasons, including income generation, cultural diplomacy, promoting innovation and productivity by gaining access to talent, and promoting campus internationalization. Although the number of students seeking education abroad is growing and is likely to continue doing so, the competition for international students is fierce.

We examine international student enrollments in postsecondary education in the top-five receiving countries-the United States, the United Kingdom, Germany, France, and Australia-summarizing the efforts of these nations to attract these students and the factors that will influence future trends. 